\title{
A new species of the genus Cyanosesia O. Gorbunov et Arita, 2001 (Lepidoptera: Sesiidae) from the island of Obi, North Maluku, Indonesia with a catalogue of the genus
}

\author{
Новый вид рода Cyanosesia O. Gorbunov et Arita, 2001 \\ (Lepidoptera: Sesiidae) с острова Оби, Северное Малуку, \\ Индонезия с каталогом рода
}

\author{
O.G. Gorbunov \\ О.Г. Горбунов
}

\begin{abstract}
A.N. Severtsov Institute of Ecology and Evolution, Russian Academy of Sciences, Leninsky prospekt 33, Moscow 119071, Russia. E-mail: gorbunov.oleg@mail.ru

Институт проблем экологии и эволюции им. А.Н. Северцова РАН, Ленинский проспект 33, Москва 119071, Россия.
\end{abstract}

KEY WORDS: Sesiini, Cyanosesia tuzovi, systematics, Oriental realm.

КЛЮЧЕВЫЕ СЛОВА: Sesiini, Cyanosesia tuzovi, систематика, Ориентальная область.

ABSTRACT. A new species, Cyanosesia tuzovi sp.n. from the island of Obi, North Maluku, Indonesia, is described and illustrated. The data on its biotope is presented and illustrated. An annotated catalogue of the genus Cyanosesia is added to this paper. The catalogue contains the following information: the references to the original descriptions, information on name-bearing types, complete bibliographies of the presented taxa, data on host plants and distribution. The holotype of the new species is deposited in the collections of the A.N. Severtsov Institute of Ecology and Evolution of the Russian Academy of Sciences, Moscow, Russia.

РЕЗЮМЕ. Приведено описание нового вида, Cyanosesia tuzovi sp.n. с острова Оби, Северное Малуку, Индонезия. Данные о его биотопе также представлены и проиллюстрированы. К статье добавлен аннотированный каталог рода Cyanosesia. Каталог содержит следующую информацию: ссылки на первоначальные описания, информацию о номенклатурных типах, полную библиографии, данные о кормовых растениях и распространении. Голотип нового вида хранится в коллекции Института проблем экологии и эволюции им. А.Н. Северцова Российской академии наук в Москве.

\section{Introduction}

During a short-time trip to North Maluku, Indonesia in February-March 2017, I could collect several very interesting species of Sesiidae with the help of artificial sex attractants produced by PHEROBANK ${ }^{\circledR}$, Wijk bij Duurstede, the Netherlands. One of the collected species was a representative of the genus Cyanosesia O. Gorbunov et Arita, 1995 [Gorbunov, 2020].

The genus Cyanosesia was established for two new species from Vietnam [Gorbunov, Arita, 1995]: C. tonkinensis O. Gorbunov et Arita, 1995, and C. vietnamica O. Gorbunov et Arita, 1995. The first of these species was selected as the type species of the genus. Currently the genus Cyanosesia consists of 17 species, including the new one described below.

The present paper presents the description of a new species, Cyanosesia tuzovi sp.n. In addition, I provide an annotated catalogue of the genus Cyanosesia, which contains updated taxonomic information including references to the original descriptions, information on name-bearing types, complete bibliographies, data on host plants and distribution.

The description of the holotype was made using a Leica EZ4 stereomicroscope with LED illuminations. Images of freshly collected moths and their habitat were taken with a Sony ${ }^{\circledR} \alpha 450$ DSLR camera equipped with a Minolta $^{\circledR} 50 \mathrm{f} / 2.8$ Macro lens. The genitalia were photographed using a Keyence ${ }^{\circledR}$ BZ-9000 Biorevo Fluorescence Microscope. The processing of all illustrations was finalized with Adobe ${ }^{\circledR}$ Photoshop ${ }^{\circledR} 2020$ software.

The material studied or mentioned herein is kept in the following collections:

BMNH - the Natural History Museum, London, UK; CAK - personal collection of Axel Kallies, Melbourne, Australia;

How to cite this article: Gorbunov O.G. 2020. A new species of the genus Cyanosesia O. Gorbunov et Arita, 2001 (Lepidoptera, Sesiidae) from the island of Obi, North Maluku, Indonesia with catalogue of the genus // Russian Entomol. J. Vol.29. No.2. P.187-194. doi: 10.15298/rusentj.29.2.11 
COGM - the collection of the A.N. Severtsov Institute of Ecology and Evolution of the Russian Academy of Sciences, Moscow, Russia;

BMHU — Bishop Museum, Honolulu, Hawaii, U.S.A. NSMT - National Museum of Nature and Science, Tsukuba, Tokyo (formerly Natural Science Museum Tokyo), Japan;

OUZM - Oxford University Museum of Natural History (Zoological Collections), Oxford University, Oxford, UK;

SMFM - Senckenberg Research Institute and Natural History Museum, Frankfurt am Main, Germany; ZISP - Zoological Institute of the Russian Academy of Sciences, St. Petersburg, Russia.

All labels of the holotype of the new species are cited verbatim. Each label is separated by semicolon marks (;), while lines on a label are shown separated by a slash ("/"). Pictures of the specimens are labeled with a number which consists of the name of the family, two consecutive digits and a year (e.g., SESIIDAE pictures №№ 0027-00282017). These numbers correspond to those of the illustrated specimens in the archives of the author. The dissected genitalia are placed in a microtube and pinned under the specimen. The genitalia number is also printed on a label (e.g., Preparation № OG-058-2018), pinned under the specimen and listed in the archives of the author.

\section{Taxonomic account}

\section{Cyanosesia tuzovi O. Gorbunov, sp.n.} Figs 1-7.

MATERIAL. Holotype $O^{7}$ (Figs 1-2) with labels: "Indonesia, N Maluku, / Obi Id., $3 \mathrm{~km} \mathrm{SW}$ Laiwui, / 012․ $23^{\prime} \mathrm{S}$, $127^{\circ} 37.33^{\prime} \mathrm{E}$, 115 m, 25.II.2017, / O. Gorbunov leg." (white); "SESIIDAE / Pictures №№ / 0027-0028-2017 / Photo by O. Gorbunov" (white); "Genitalia examined / by O. Gorbunov / Preparation № / OG-058 2018" (white); "HOLOTYPUS $\sigma^{r} /$ Cyanosesia tuzovi / O. Gorbunov, 2020 / O. Gorbunov des., 2017" (red).

DESCRIPTION. Male (holotype) (Figs 1-2). Alar expanse $19.4 \mathrm{~mm}$; body length $9.5 \mathrm{~mm}$; forewing $8.6 \mathrm{~mm}$; antenna $4.8 \mathrm{~mm}$.

Head with antenna black with dark greenish-violet sheen dorsally and dark brown ventrally; scapus black with dark greenish sheen dorsally and lemon-yellow ventrally; frons dark gray with bright blue-violet sheen and a broad showwhite stripe laterally; both basal and apical joints of labial palpus black with dark violet sheen, mid joint lemon-yellow with an admixture of black scales with dark violet sheen dorso-distally; vertex entirely black with bright bronze-green sheen; occipital fringe black with dark violet sheen dorsally and lemon-yellow laterally.

Thorax with patagia black with dark violet sheen dorsally and lemon-yellow laterally; tegula black with bright violetpurple sheen, a small lemon-yellow spot anteriorly and a few lemon-yellow scales on inner margin; mesothorax black with violet-purple sheen; metathorax black with dark violet sheen and two lemon-yellow spots; thorax laterally black with blueviolet sheen, a small lemon-yellow spot at bottom of mesomeron and with a narrow lemon-yellow stripe on posterior margin of mesomeron; posteriorly both metepimeron and metameron dark gray with blue-violet sheen covered with long white hairlike scales. Legs with neck plate entirely lemon-yellow; fore coxa black with bright bluish sheen and a large lemon-yellow spot subdistally; fore femur dark brown to black with blueviolet sheen and a few yellow elongate scales interior-distally; fore tibia ventrally yellow, dorsally dark brown to black with a few yellow scales; fore tarsus dark brown to black with bronze sheen dorsally and yellow with golden sheen ventrally; mid coxa black with bright greenish sheen and a few yellow scales internally; mid femur dark brown to black with blue-violet sheen and a few yellow elongate scales interior-distally and a few white hairy-like scales interior-basally; mid tibia black with violet sheen externally and yellow both dorsally and internally, ventrally mixed with black with violet sheen and yellow scales; spurs dark brown to black with bronze-violet sheen; mid tarsus dark brown to black with blue-violet sheen externally and yellow with golden sheen internally; hind coxa black with bright greenish sheen and a few yellow scales internally; hind femur dark brown to black with blue-violet sheen and a few yellow elongate scales interior-distally; hind tibia black with blue-violet sheen and a narrow yellow stripe dorsally; spurs bark brown to black externally and yellow with golden sheen internally; mid tarsus dark brown to black with blue-violet sheen and an admixture of yellow scales dorsally on basal tarsomeres; in addition, scales both on hind tibia distally of mid spurs and on dorsal part of basal tarsomere of hind tarsus visibly elongate and form a hind-leg tuft. Forewing transparent; basally black with dark greenish sheen and a few lemon-yellow scales; costal and anal margins, $\mathrm{CuA}$-stem, discal spot, veins $\mathrm{R}_{4+5}-\mathrm{CuA}_{2}$ and cuneiform opaque lines between veins $\mathrm{R}_{3}-\mathrm{CuA}$, black with dark violet sheen; cilia black with dark violet sheen; discal spot extremely narrow, level to vein $\mathrm{M}_{2}$ about 0.09 times as broad as external transparent area; ventrally costal and anal margins, $\mathrm{CuA}$-stem, discal spot, veins $\mathrm{R}_{4+5}-\mathrm{CuA}$ and cuneiform opaque lines between veins $\mathrm{R}_{3}-$ $\mathrm{CuA}$ black with dark blue-violet sheen and with an admixture of individual yellow scales; cilia dark brown to black with blue-violet sheen. Hindwing transparent; dorsally veins and outer margin black with dark violet sheen; discal spot undeveloped; outer margin extremely narrow, consists of one or two rows of scales; cilia black with dark violet sheen; ventrally veins and outer margin black with dark blue-violet sheen and with an admixture of individual yellow scales; cilia dark brown to black with blue-violet sheen.

Abdomen dorsally black with greenish-violet sheen; tergites 3 and 4 each with a narrow lemon-yellow stripe proximally; tergite 5 with a few lemon-yellow scales latero-proximally; tergites 6 and 7 each with a narrow lemon-yellow stripe distally; ventrally black with blue-violet sheen; sternite $1+2$ pale lemonyellow proximally; sternite 4 with a narrow lemon-yellow stripe proximally; anal tuft small, black with dark violet sheen.

Male genitalia (holotype) (genital preparation № OG058-2018) (Figs 3-6). Tegumen-uncus complex well-developed, with numerous setae on inner surface of uncus ventroapically; tegumen relatively long and broad; gnathos rather well-developed, visibly asymmetrical and rounded distally, covered with minute spines (Fig. 3); valva (Fig. 4) pentagonaloval, densely covered with multifurcate scale-like setae in dorsal half and with sparse hairs in ventral half; crista sacculi well-developed, triangular-oval, broad, with hair-like setae on anterior margin; saccus (Fig. 5) narrow, rounded basally, about as long as vinculum; aedeagus (Fig. 6) slightly longer than valva, relatively thin; vesica with numerous pointed spinules.

INDIVIDUAL VARIABILITY. Unknown.

DIFFERENTIAL DIAGNOSIS. By the structure of the male genitalia, this new species seems to be closest to C. leleji O. Gorbunov et Arita, 2016, from the male of which it can be distinguished by the colouration of the bright coloured scales of the head, thorax and abdomen, which are lemon-yellow in 


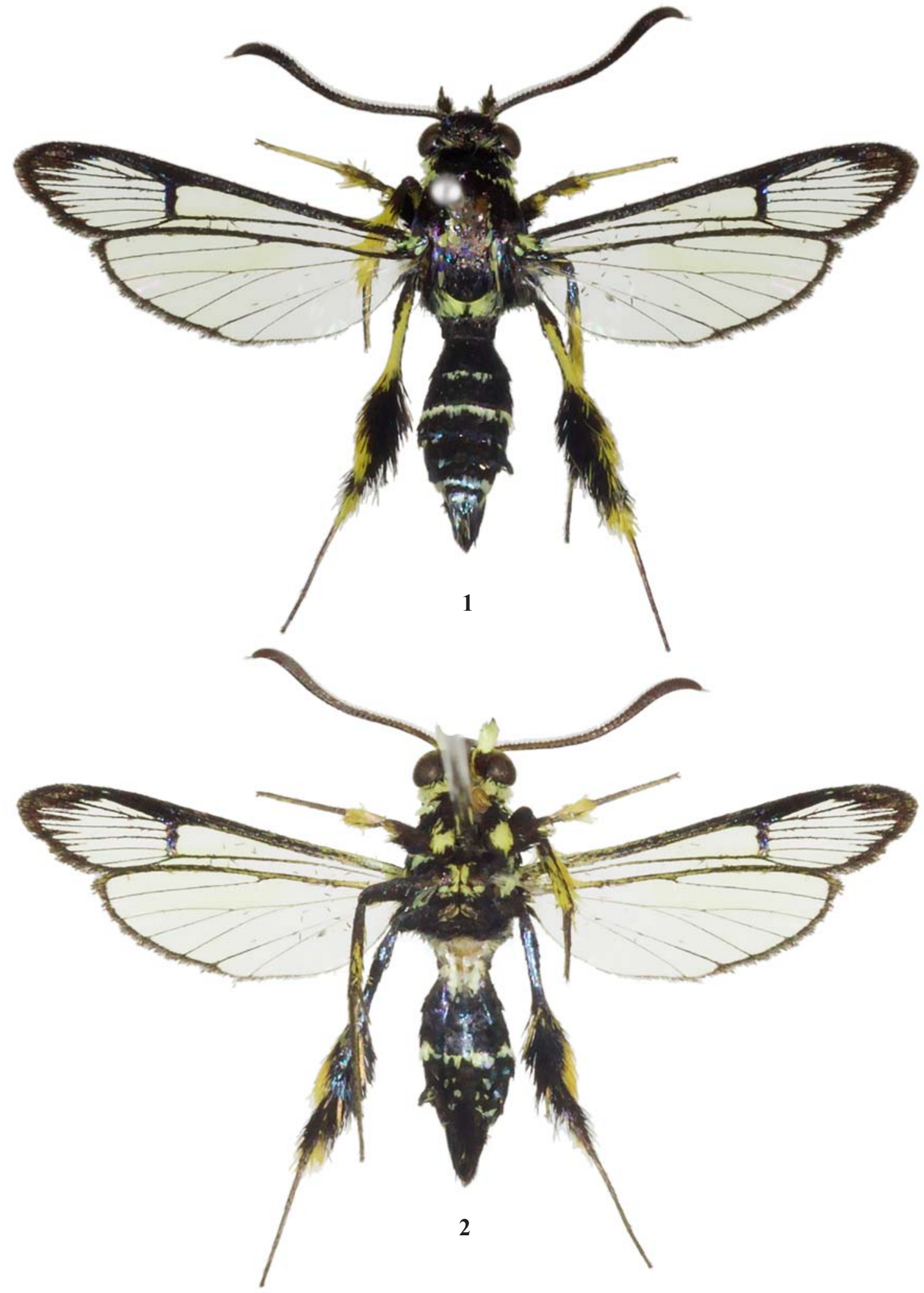

Figs 1-2. Cyanosesia tuzovi sp.n.: 1 - holotype, upside. Sesiidae picture № 0027-2017. Alar expanse $19.4 \mathrm{~mm} ; 2$ - ditto underside. Sesiidae picture № 0028-2017.

Рис. 1-2. Cyanosesia tuzovi sp.n. : 1 — голотип, сверху. Sesiidae снимок № 0027-2017. Размах крыльев 19.4 mm; 2 — вид снизу. Sesiidae снимок № 0028-2017. 
the new species instead of yellow in C. leleji. Besides this, these two species are distinguished by the colouration of the labial palpus (basal join black with bronze sheen externally and pale yellow internally, remaining joints yellow with a narrow black stripe externally in C. leleji, vs. both basal and apical joints black with dark violet sheen, mid joint lemonyellow with an admixture of black scales with dark violet sheen dorso-distally in C. tuzovi sp.n.), thorax laterally (brown with violet sheen, with a large dark yellow with golden sheen spot medially in the species compared, vs. black with blueviolet sheen, a small lemon-yellow spot at bottom of mesomeron and with a narrow lemon-yellow stripe on posterior margin of mesomeron in C. tuzovi sp.n.), neck plate (dark brown with bronze sheen in C. leleji, vs. entirely lemonyellow in the new species), hind tibia (dark brown to black with greenish sheen, a broad yellow band at base of mid spurs and with a yellow-orange spot exterior-distally in the species compared, vs. tibia black with blue-violet sheen and a narrow yellow stripe dorsally in the new species), and abdomen (dorsally black with green-blue sheen; tergite 4 with a broad yellow-orange stripe anteriorly; tergite 5 with a narrow yellow-orange stripe anteriorly; tergites 6 and 7 each with a narrow yellow-orange stripe posteriorly; ventrally dark brown to black with greenish sheen; sternites 4 and 5 each with a broad yellow-orange stripe anteriorly; sternite 6 with a few yellow scales posteriorly in C. leleji, vs. black with greenishviolet sheen; tergites 3 and 4 each with a narrow lemonyellow stripe proximally; tergite 5 with a few lemon-yellow scales latero-proximally; tergites 6 and 7 each with a narrow lemon-yellow stripe distally; ventrally black with blue-violet sheen; sternite 1+2 pale lemon-yellow proximally; sternite 4 with a narrow lemon-yellow stripe proximally $C$. tuzovi

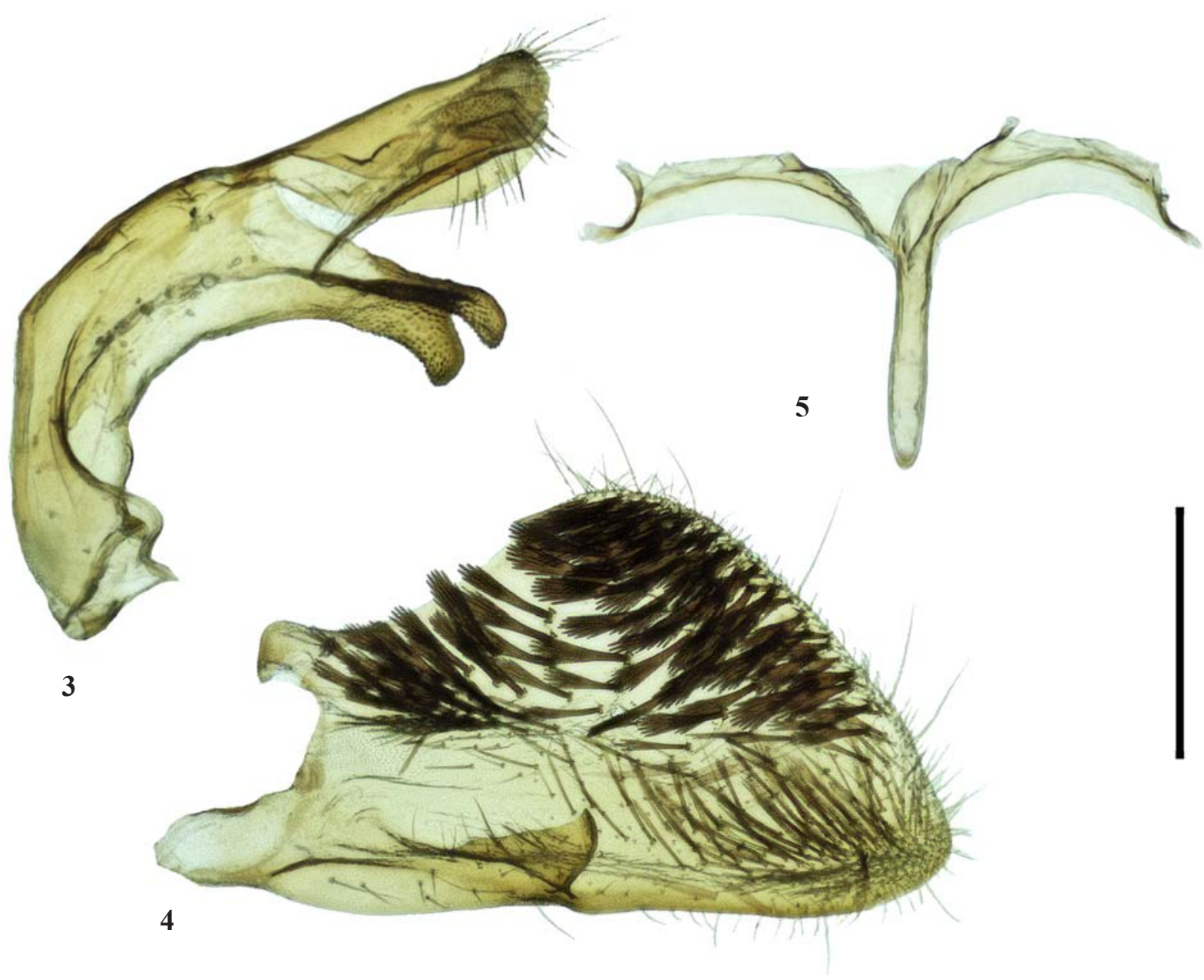

6

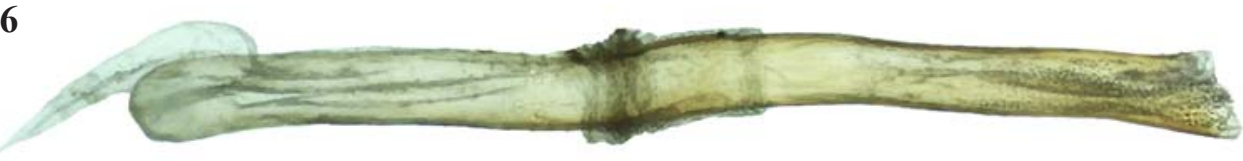

Figs 3-6. Male genitalia of Cyanosesia tuzovi sp.n., holotype. Genital preparation № OG-058-2018: 3 — tegumen-uncus complex; 4 valva; 5 - saccus; 6 - aedeagus. Scale bar $0.5 \mathrm{~mm}$.

Рис. 9-12. Гениталии самца Cyanosesia tuzovi sp.n., голотип. Препарат гениталий № OG-058-2018: 3 — тегумен-ункус комплекс; 4 - вальва; 5 - саккус; 6 - эдеагус. Масштаб 0,5 мм. 
sp.n.). In addition, these two species differ from each other by the conformation of the male genitalia, especially by the shape of both crista sacculi and saccus [compare Figs 4 and 5 with figs 10 and 11 in Gorbunov, Arita, 2016: 38].

By the colouration of the legs and abdomen and by the conformation of both forewing and male genitalia, the new species is clearly distinguishable from all of its congeners.

BIONOMICS. The larval host-plant is unknown. The holotype was attracted by unspecifical artificial sex pheromones. It came to lures right after noon.

HABITAT. In the island of Obi, North Maluku, this species was collected on a clearing among the secondary rainforest in the vicinity of the town of Labuha (Fig. 7).

DISTRIBUTION. Known from the type locality on the islands of Obi, North Maluku, Indonesia.

ETYMOLOGY. This new species is named after my friend Dr. Vasily K. Tuzov, a great expert on Rhopalocera of the world fauna, who courageously shares with me all the hardships in our many joint entomological trips to different parts of the globe.

\section{Catalogue of the genus Cyanosesia O. Gor- bunov et Arita 1995}

\section{Cyanosesia O. Gorbunov et Arita, 1995}

"Cyanosesia gen. nov." - Gorbunov, Arita, 1995: 74. Type species: Cyanosesia tonkinensis O. Gorbunov et Arita, 1995, by original designation.
LITERATURE. Kallies, 2003: 161 (Cyanosesia); Kallies, Arita, 2004: 67, 84 (Cyanosesia); Pühringer, Kallies, 2004: 11 (Cyanosesia); Kallies, 2011: 152 (Cyanosesia); Gorbunov, Arita, 2016: 35, 36 (Cyanosesia).

RANGE. Oriental realm from East India (Meghalaya) in the west to the Philippines (Samar) and Borneo (Sabah) in the east and from South China (Gong Kong, Guangdong) and Taiwan in the north and Java and Wallacea (Sulawesi and Obi) in the south.

Cyanosesia borneensis Kallies, 2003

“Cyanosesia borneensis sp. n.”- Kallies, 2003: 161, figs 1, 2. Type locality: "North Borneo (SE) [Malaysia, Sabah] / Forest Camp, $19 \mathrm{~km} / \mathrm{N}$ of Kalabakan / ...". Holotype + (BMHU).

LITERATURE. Kallies, Arita, 2004: 67 (Cyanosesia borneensis); Pühringer, Kallies, 2004: 11 (Cyanosesia borneensis); Gorbunov, Arita, 2016: 36 (Cyanosesia borneensis).

FLIGHT PERIOD. The holotype was collected on November 1.

HOST PLANT. Unknown.

DISTRIBUTION. It is known only from the type locality in Sabah, Indonesia.

\section{Cyanosesia cyanolampra (Diakonoff, 1968 [“1967”])*}

"Sura cyanolampra, new species" — Diakonoff, 1968: 229, figs 331, 711-712. Type locality: "Luzon, Los Baños ..." [= Philippines: Luzon, Laguna, Los Baños]. Holotype + (USNM).

According to Clarke, the actual date of publication of the 257 issue of the Bulletin of the United States National Museum is January 31st, 1968 ("1868" in the text!) [Clarke, 1980].

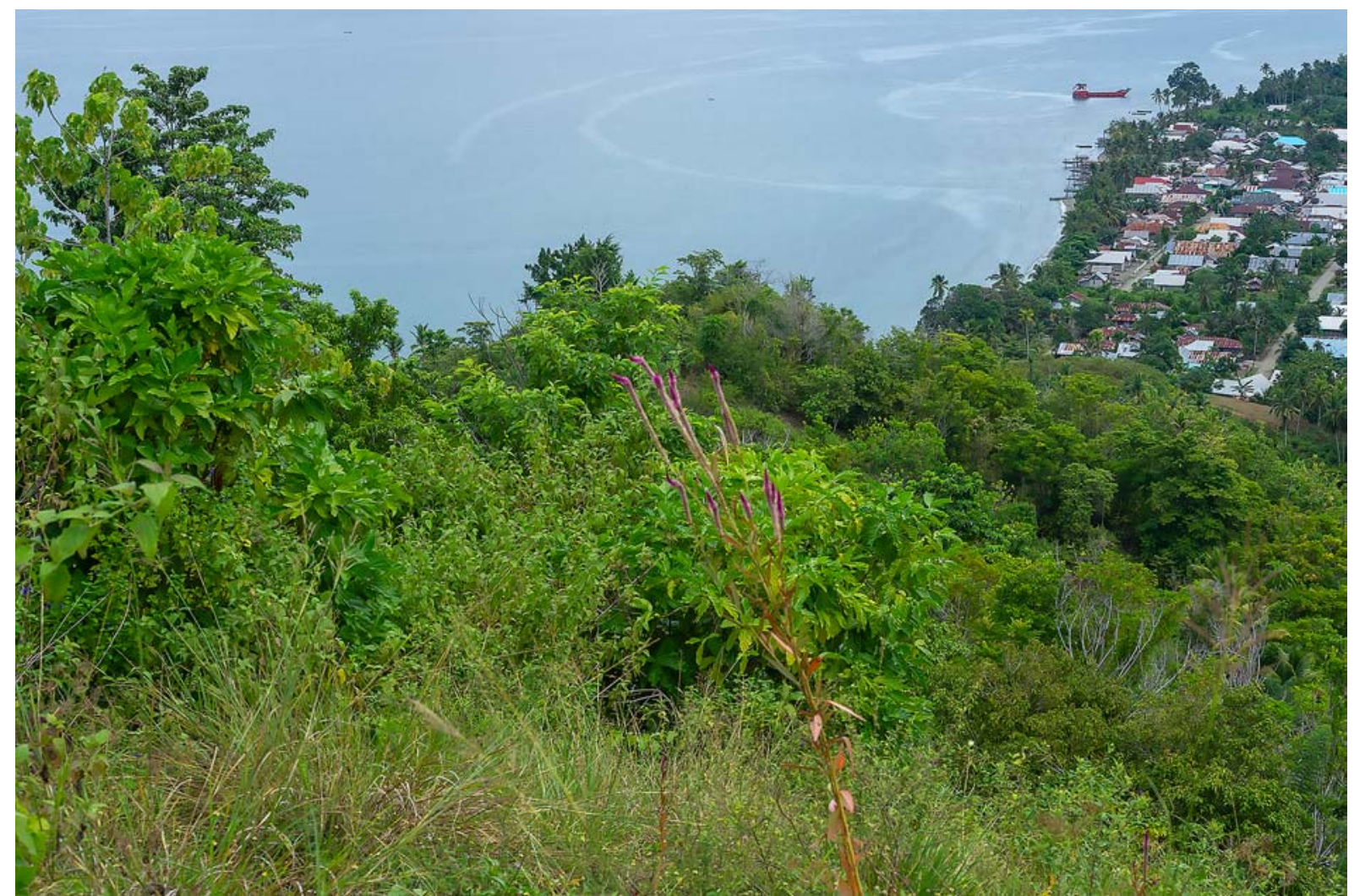

Fig. 7. Habitat of Cyanosesia tuzovi sp.n. : Indonesia, North Maluku, Obi Island, $3 \mathrm{~km} \mathrm{SW}$ of Laiwui, $01^{\circ} 21.43^{\prime} \mathrm{S}, 1^{\circ} 7^{\circ} 37.33^{\prime} \mathrm{E}, 1^{115}$ m, 25.II.2017. Photo by O. Gorbunov.

Рис. 7. Биотоп Cyanosesia tuzovi sp.n. : Индонезия, Северное Малуку, остров Оби, 3 км Ю3 Лайвуя, $01^{\circ} 21.43^{\prime}$ ю.ш., $127^{\circ} 37.33^{\prime}$ в.д., 115 м, 25.II.2017. Фото О. Горбунова. 
LITERATURE. Heppner, Duckworth, 1981: 25 (Sura cyanolampra); Kallies, Arita, 2004: 67, 84, 89 (Cyanosesia cyanolampra); Pühringer, Kallies, 2004: 11 (Cyanosesia cyanolampra); Gorbunov, Arita, 2016: 36 (Cyanosesia cyanolampra).

FLIGHT PERIOD. One paratype was collected on September 1 .

HOST PLANT. Unknown.

DISTRIBUTION. It is known from a few localities on the island of Luzon, the Philippines.

Cyanosesia cyanosa Kallies et Arita, 2004

"Cyanosesia cyanosa sp. n." - Kallies, Arita, 2004: 67, 88, figs 14, 28. Type locality: "N. Vietnam, Vinh Phu Prov., Tam Dao, $930 \mathrm{~m}, . . . "$. Holotype $\sigma^{\prime}$ (CAK).

LITERATURE. Pühringer, Kallies, 2004: 11 (Cyanosesia cyanosa); Gorbunov, Arita, 2016: 36 (Cyanosesia cyanosa).

FLIGHT PERIOD. The holotype of this species was collected on June 25-26.

HOST PLANT. Unknown.

DISTRIBUTION. It is known from the type locality in North Vietnam only.

Cyanosesia formosana Arita et O. Gorbunov, 2002

"Cyanosesia formosana sp. nov." - Arita, Gorbunov, 2002: 234, figs 15, 30a-e. Type locality: "Taiwan, Nantou Hsien, Kuantaoshan, 1,300 m ...". Holotype $\sigma^{7}$ (NSMT).

LITERATURE. Kallies, Arita, 2004: 67 (Cyanosesia formosana); Pühringer, Kallies, 2004: 11 (Cyanosesia formosana); Gorbunov, Arita, 2016: 36 (Cyanosesia formosana).

FLIGHT PERIOD. The type series was collected in late June and early July.

HOST PLANT. Unknown.

DISTRIBUTION. This species is known from the island of Taiwan only.

\section{Cyanosesia hypochalcia (Hampson, 1919)}

"Synanthedon hypochalcia n. sp." - Hampson, 1919: 60. Type locality: "Assam, Khásis, ..." [= India: Meghalaya, Khasi Hills]. Holotype $\sigma^{7}(\mathrm{BMNH})$.

LITERATURE. Dalla Torre, Strand, 1925: 28 (Synanthedon hypochalcia); Gaede, 1933: 780 (Synanthedon hypochalcia); Heppner, Duckworth, 1981: 31 (Synanthedon hypochalcia); Kallies, 2003: 161, 164 (Cyanosesia hypochalcia); Kallies, Arita, 2004: 67 (Cyanosesia hypochalcia); Pühringer, Kallies, 2004: 11 (Cyanosesia hypochalcia); Gorbunov, Arita, 2016: 36 (Cyanosesia hypochalcia).

FLIGHT PERIOD. The type series was collected in April. HOST PLANT. Unknown.

DISTRIBUTION. This species is known only from the type locality in the state Meghalaya in India.

Cyanosesia javana O. Gorbunov et Kallies, 1998

"Cyanosesia javana sp. nov." - Gorbunov, Kallies, 1998: 461, figs 1, 3a-d. Type locality: "W. Java: G[unung] Malang" [Indonesia, western Java, Mt. Malang]". Holotype or (BMNH).

LITERATURE. Arita, Gorbunov, 2002: 237 (Cyanosesia javana); Kallies, 2003: 161, 164 (Cyanosesia javana); Kallies, Arita 2004: 67 (Cyanosesia javana); Pühringer, Kallies, 2004: 11 (Cy anosesia javana); Gorbunov, Arita, 2016: 36 (Cyanosesia javana).

FLIGHT PERIOD. Unknown.

HOST PLANT. Unknown.

DISTRIBUTION. It is known only from the type locality on the island of Java, Indonesia.

Cyanosesia leleji O. Gorbunov et Arita, 2016

"Cyanosesia leleji, sp.n.” - Gorbunov, Arita, 2016: 35, figs 113. Type locality: "S.E.Sulawesi / Tiu Lapolu / ... [= Indonesia: Sulawesi Tenggara, Kota Kendari, Lapulu]". Holotype + (ZISP).

LITERATURE. Present publication: 192 (Cyanosesia leleji).

FLIGHT PERIOD. The type series was collected in March.
HOST PLANT. Unknown.

DISTRIBUTION. It is known only from the type locality in South-East Sulawesi, Indonesia.

Cyanosesia litseavora Kallies et Arita, 2004

"Cyanosesia litseavora sp. n." - Kallies, Arita, 2004: 67, 85, figs 11-12, 27, 34. Type locality: "N. Vietnam, Vinh Phu Prov., Tam Dao, 1100 m, ...". Holotype or (NSMT).

LITERATURE. Pühringer, Kallies, 2004: 11 (Cyanosesia litseavora); Gorbunov, Arita, 2016: 36, 39 (Cyanosesia litseavora).

FLIGHT PERIOD. Moths on the wing in late September - early October.

HOST PLANT. Larvae in trunks of Litsea umbellate (Lauraceae).

DISTRIBUTION. It is known from the type locality in North Vietnam only.

\section{Cyanosesia meyi Kallies et Arita, 1998}

"Cyanosesia meyi sp. nov." - Kallies, Arita, 1998: 249, figs 3, 20. Type locality: "Phil[ippines]., E[ast]. Samar, near Taft, ..." [= Philippines: Eastern Samar, Taft]. Holotype $\sigma^{7}$ (SMFM).

LITERATURE. Kallies, Arita, 1998: 250 (Cyanosesia meyi); Kallies, 2003: 161 (Cyanosesia meyi); Arita, Gorbunov, 2002: 237 (Cyanosesia meyi); Kallies, Arita, 2004: 70 (Cyanosesia meyi); Pühringer, Kallies, 2004: 11 (Cyanosesia meyi); Gorbunov, Arita, 2016: 36 (Cyanosesia meyi).

FLIGHT PERIOD. The holotype was collected in early September.

HOST PLANT. Unknown.

DISTRIBUTION. It is known only from the island of Samar, the Philippines.

Cyanosesia ormosiae Kallies, 2011

"Cyanosesia ormosiae sp. n." — Kallies, 2011: 152, figs 1-3, 9, 10. Type locality: “"Hong Kong: | New Territories, | Ma On Shan | ...". Holotype O' (BMNH).

LITERATURE. Kallies et al., 2014: 587 (Cyanosesia ormosiae); Gorbunov, Arita, 2016: 36 (Cyanosesia ormosiae).

FLIGHT PERIOD. Unknown. Larvae of the type series were collected in late May.

HOST PLANT. Larvae in trunks of Ormosia pachycarpa (Fabaceae).

DISTRIBUTION. Known only from the type locality in Hong Kong, China.

Cyanosesia panorpaeformis

(Boisduval, 1875 [“1874”]) **

"S.[esia] Panorpaeformis. Boisd." - Boisduval, 1875: 393, pl. 9, fig. 6. Type locality: “... les forêts de l'île de Luçon.” [= Philippines: Luzon]. 2 Syntypes (?)

LITERATURE. Dalla Torre, Strand, 1925: 161 (Paranthrene panorpaeformis); Heppner, Duckworth, 1981: 24 (Paranthrene panorpaeformis); Kallies et al., 2014: 187 (Cyanosesia panorpaeformis); Gorbunov, Arita, 2016: 36 (Cyanosesia panorpaeformis).

FLIGHT PERIOD. Unknown.

HOST PLANT. Unknown.

DISTRIBUTION. It is known only from the type locality on the island of Luzon, the Philippines.

Cyanosesia pelocroca (Diakonoff, 1968 ["1967'])

"Glossosphecia pelocroca, new species" - Diakonoff, 1968: 225, figs 344, 706-707. Type locality: "Luzon, Los Baños ..." [= Philippines: Luzon, Laguna, Los Baños]. Holotype + (USNM).

* Butler [1876: 513] wrote: “Dr. Boisduval's long expected work on the Sphingidae has recently appeared, bearing date 1874; that it was not, however, procurable earlier than February 22nd, 1875, I have evidence in a letter from the author, dated 18th of February, 1875, ...". 
LITERATURE. Kallies, Arita, 1998: 247, 248 (Cyanosesia pelocroca); Kallies, 2003: 161 (Cyanosesia pelocroca); Kallies, Arita, 2004: 70 (Cyanosesia pelocroca); Pühringer, Kallies, 2004: 11 (Cyanosesia pelocroca); Gorbunov, Arita, 2016: 36 (Cyanosesia pelocroca).

FLIGHT PERIOD. Unknown.

HOST PLANT. Unknown.

DISTRIBUTION. It is known from the type locality on the island of Luzon, the Philippines.

Cyanosesia philippina O. Gorbunov et Kallies, 1998

"Cyanosesia philippina sp. nov." - Gorbunov, Kallies, 1998: 458, figs 2, 4a-d. Type locality: "Surigao, Mindanao" [Philippines, northern Mindanao Island, Province of Surigao]" Holotype o" (BMNH).

LITERATURE. Kallies, Arita, 1998: 350, fig. 4 (Cyanosesia philippina); Gorbunov, Arita, 2002: 237 (Cyanosesia philippina); Kallies, 2003: 161 (Cyanosesia philippina); Kallies, Arita, 2004: 70 (Cyanosesia philippina); Pühringer, Kallies, 2004: 11 (Cyanosesia philippina); Gorbunov, Arita, 2016: 36 (Cyanosesia philippina). May.

FLIGHT PERIOD. One paratype was collected in early

HOST PLANT. Unknown.

DISTRIBUTION. Known from islands of Luzon and Mindanao, the Philippines.

Cyanosesia tonkinensis O. Gorbunov et Arita, 1995

“Cyanosesia tonkinensis sp. nov." - Gorbunov, Arita, 1995: 77, figs 3, 11, 13a-e. Type locality: "North Vietnam, Vinh Phu Prov., ca. $100 \mathrm{~km} \mathrm{~N}$ of Hanoi, Tam Dao Mt., 950 m.". Holotype $\sigma^{7}$ (COGM).

LITERATURE. Zukowsky, 1929: 35 (Paranthrene trizonata Hampson, 1900); Gorbunov, Kallies, 1998: 457, 460, 461, 464 (Cyanosesia tonkinensis); Gorbunov, Arita, 2002: 237 (Cyanosesia tonkinensis); Kallies, 2003: 161, 164 (Cyanosesia tonkinensis); Kallies, Arita, 2004: 70, 85, figs 13, 35 (Cyanosesia tonkinensis); Pühringer, Kallies, 2004: 11 (Cyanosesia tonkinensis); Kallies, 2007: 394 (Cyanosesia tonkinensis); Kallies et al., 2014: 587 (Cy anosesia tonkinensis); Gorbunov, Arita, 2016: 36 (Cyanosesia tonkinensis).

FLIGHT PERIOD. The holotype was collected on May 10. Other specimens were collected in early July and late September.

HOST PLANT. Litsea umbellate (Lauraceae).

DISTRIBUTION. Known from South China (Guangdong) and North Vietnam (Vinh Phu).

Cyanosesia treadawayi Kallies et Arita, 1998

"Cyanosesia treadawayi sp. nov." - Kallies, Arita, 1998: 246, figs 1, 2, 19, 28. Type locality: "P[hilippine]. I[slands]., C[entral]. Leyte, Mahaplang Hilusig, $700 \mathrm{~m}$. Mt Balocaue, ...”. Holotype $\sigma^{7}$ (SMFM)

LITERATURE. Kallies, Arita, 1998: 249 (Cyanosesia treadawayi); Arita, Gorbunov, 2002: 237 (Cyanosesia treadawayi); Kallies, 2003: 161 (Cyanosesia treadawayi); Kallies, Arita, 2004: 70 (Cyanosesia treadawayi); Pühringer, Kallies, 2004: 11 (Cyanosesia treadawayi); Gorbunov, Arita, 2016: 36 (Cyanosesia treadawayi). June.

FLIGHT PERIOD. The type series was collected in late

HOST PLANT. Unknown.

DISTRIBUTION. This species is known from the island of Leyte, the Philippines.

\section{Cyanosesia tuzovi sp.n.}

“Cyanosesia tuzovi sp.n.” — present publication, Figs 1-6. Type locality: Indonesia, North Maluku, Obi Id., 3 km SW Laiwui. Holotype $\sigma^{7}$ (COGM).

FLIGHT PERIOD. The holotype was collected in late February.

HOST PLANT. Unknown.
DISTRIBUTION. Known from the type locality on the island of Obi, North Maluku, Indonesia.

Cyanosesia vietnamica O. Gorbunov et Arita, 1995

"Cyanosesia vietnamica sp. nov." - Gorbunov, Arita, 1995: 79, figs 4, 18. Type locality: "Vietnam, Pahia (Arbe Signal), ..." [= North Vietnam: ]. Holotype + (MHNG).

LITERATURE. Gorbunov, Kallies, 1998: 457, 461, 464 (Cyanosesia vietnamica); Kallies, 2003: 161 (Cyanosesia vietnamica); Kallies, Arita, 2004: 70 (Cyanosesia vietnamica); Pühringer, Kallies, 2004: 11 (Cyanosesia vietnamica); Gorbunov, Arita, 2016: 36, 39 (Cyanosesia vietnamica).

FLIGHT PERIOD. The holotype was collected on May 23.

HOST PLANT. Unknown.

DISTRIBUTION. North Vietnam.

Acknowledgements. I would like to express my cordial thanks to Mr. Maxim B. Markhasyov, Dr. Vasily K. Tuzov and Prof. Dmitry G. Zamolodchikov (all from Moscow, Russia) for the company and help during our successful trip to North Maluku, Indonesia in 2017. I am indebted to $\mathrm{Mr}$. Vlad Proklov (London, England) for carefully checking the English of an advanced draft.

The study was conducted using the equipment of the Joint Usage Center "Instrumental methods in ecology" at the A.N. Severtsov Institute of Ecology and Evolution, Russian Academy of Sciences (Moscow, Russia).

\section{References}

Arita Y., Gorbunov O.G. 2002. Sesiidae of Taiwan. II. The tribes Osminiini, Melittiini and Sesiini // Jpn. J. syst. Ent. Vol.8. No.2. P.199-241.

Boisduval J.A. 1875. Sphingides, Sésiides, Castnides // Boisduval J.A., Guénée A. (eds). Histoire naturelle des insects: species général des Lépidoptères Hétérocères. Vol.1. Paris: Librairie encyclopédique de Roret. 568 pp.

Butler A.G. 1876. Revision of the Heterocerous Lepidoptera of the family Sphingidae // Trans. zool. soc. London. Vol.9. No.10. P.511-644. Pls60-64.

Clarke J.F.G. 1980. Transfer of Microlepidoptera types to the Smithsonian Institution // Proc. Ent. soc. Washington. Vol.82. No.4. P.540.

Dalla Torre K.W., Strand E. 1925. Aegeriidae // Strand E. (Hrsg.). Lepidopterorum Catalogus. Bd.31. Berlin: W. Junk. 202 S.

Diakonoff A.N. 1968. Microlepidoptera of the Philippine Islands // U.S. Nat. Mus. Bull. No.257. P.1-484.

Gaede M. 1933. Family Aegeriidae // Seitz A. (Hrsg.). Die GrossSchmetterlinge der Erde: eine systematische Bearbeitung der bis jetzt bekannten Gross-Schmetterlinge. II. Abteilung - Exotische Fauna. Bd.10. Die Indo-Australischen Spinner und Schwärmer. Stuttgart: A.Kernen Verlag. S.777-802. Taf.94-95.

Gorbunov O.G. 2020. To the morphology and synonymy of insufficiently known Melittia rutilipes Walker, 1865 ["1864"] (Lepidoptera, Sesiidae) // Russian Entomol. J. Vol.29. No.1. P.87-92.

Gorbunov O.G., Arita Y. 1995. New and poorly known clearwing moth taxa from Vietnam (Lepidoptera, Sesiidae) // Trans. Lepid. Soc. Jpn. Vol.46. No.2. P.69-90.

Gorbunov O.G., Arita Y. 2016. A new species of the genus Cyanosesia O. Gorbunov et Arita from South-East Sulawesi, Indonesia (Lepidoptera: Sesiidae) // Euroasian Ent. J. Vol.15. No.1. P.3539.

Gorbunov O.G., Kallies A. 1998. Two new species of the genus Cyanosesia Gorbunov \& Arita, 1995 (Lepidoptera, Sesiidae) from the Oriental Region // Nachr. Ent. Ver. Apollo (N.F.). Suppl.17. P.457-464.

Hampson G. F. 1919. A classification of the Aegeriadae [sic] of the Oriental and Ethiopian Regions // Novitates Zoologicae. Vol.26.No.1. P.46-119. 
Heppner J.B., Duckworth W.D. 1981. Classification of the Superfamily Sesioidea (Lepidoptera, Ditrysia) // Smithsonian Contr. Zool. Vol.314. P.1-144.

Kallies A. 2003. Two new species of Sesiini from the Oriental Region (Lepidoptera: Sesiidae, Sesiinae) // Nachr. Ent. Ver. Apollo (N.F.). Vol.23. No.4. P.161-166.

Kallies A. 2007. A revision of the clearwing moth species described by Zukowsky from China with additional notes on Sesiidae species from the Mell collection (Sesiidae) // Nota lepidopterologica. Vol.30. No.2. P.387-396.

Kallies A. 2011. New species and taxonomic changes in Sesiini from Asia and Europe (Sesiidae) // Nota lepidopterologica. Vol.34. No.2. P.151-161.

Kallies A., Arita Y. 1998. New and little known clearwing moths (Lepidoptera, Sesiidae) from the Philippine Islands // Trans.
Lepid. Soc. Jpn. Vol.49. No.4. P.245-270.

Kallies A., Arita Y. 2004. A survey of the clearwing moths of the tribe Sesiini (Lepidoptera, Sesiidae) from Vietnam and adjacent countries with a synopsis of the Oriental Sesiini fauna // Tinea. Vol.18.No.1. P. 65-95.

Kallies A., Arita Y., Owada M., Wang M. 2014. Laetosphecia, a new genus of clearwing moths from south-eastern China, with a brief review of the Sesiini from China (Lepidoptera, Sesiidae) // Zootaxa. Vol.3895. No.4. P.581-589.

Pühringer F., Kallies A. 2004. Provisional checklist of the Sesiidae of the world (Lepidoptera: Ditrysia) // Mitt. Ent. Arb.gem. Salzkammergut. Vol.4. P.1-85.

Zukowsky B. 1929. Beiträge zur Fauna sinica (VIII). Die südchinesischen Aegeriiden der Sammlung Mell // Int. Ent. Z., Guben. Bd.23. S.33-37. 